\title{
TINDAK PIDANA PERSETUBUHAN PADA ANAK DITINJAU DARI HUKUM POSITIF DAN HUKUM ISLAM
}

\author{
Mega Widyawati \\ Magister Hukum Universitas Semarang
}

\begin{abstract}
ABSTRAK
Tujuan dari penelitian ini adalah untuk mengetahui tindak pidana persetubuhan apada anak ditinjau dari hukum positif dan hukum islam. Para remaja yang masih mencari jati dirinya menjadikan salah pergaulan dan salah menggunakan teknologi yang ada. Akibatnya semakin banyaknya kejahatan yang dilakukan pada usia muda, usia yang seharusnya untuk mencari ilmu. Sehingga banyaknya pelaku tindak pidana persetubuhan pada anak menurut hukum positif dan hukum Islam, selain itu juga pertimbangan hakim dalam menjatuhkan putusan terhadap pelaku tindak pidana persetubuhan pada anak menurut hukum positif dan hukum Islam didasarkan pada dakwaan, pembuktian, fakta-fakta dalam persidangan, tuntutan, unsur-unsur Pasal 81 ayat (2) UU No. 35 Tahun 2014 tentang perubahan atas UU No. 23 tahun 2002 tentang perlindungan anak yang terpenuhi. Metode yang digunakan yuridis normatif. Temuan atau kesimpulan adalah dalam pemidanaan terhadap pelaku tindak pidana persetubuhan jika ditinjau dari hukum positif dapat diberikan sanksi pidana penjara dan sanksi denda, apabila dari hukum islam dapat diberikan sanksi dera atau cambukan 100 kali kedua belah pihak yang melakukan zina. Dan pertimbangan hakim dalam menjatuhkan putusan terhadap pelaku harus berdasarkan fakta-fakta dalam persidangan serta pertimbangan yuridis maupun pertimbangan sosiologis.
\end{abstract}

Kata kunci : Tindak pidana; persetubuhan; anak; pemidanaan; zina 


\title{
CRIMINAL ACTS OF CHILDREN ARE REVIEWED FROM POSITIVE LAW AND ISLAMIC LAW
}

\author{
Mega Widyawati \\ Master of Law, University of Semarang
}

\begin{abstract}
The purpose of this study is to determine the crime of sexual intercourse in children in terms of positive law and Islamic law. The teenagers who are still looking for their identity make a wrong association and wrong to use existing technology. As a result, more and more crimes are committed at a young age, the age that is supposed to seek knowledge. So that the number of perpetrators of sexual intercourse on children according to positive law and Islamic law, in addition it is also the consideration of judges in passing the verdict on the perpetrators of sexual intercourse on children according to positive law and Islamic law based on the indictment, proof, facts in the trial, prosecution, elements of Article 81 paragraph (2) of Law no. 35 of 2014 concerning amendments to Law No. 23 of 2002 concerning child protection which is fulfilled. The method used is normative juridical. The findings or conclusions are in the conviction of perpetrators of sexual intercourse if in terms of positive law sanctions can be given imprisonment and fines, if from Islamic law sanctions can be flagged or whipped 100 times both parties who commit adultery. And the judge's judgment in issuing a verdict against the perpetrator must be based on the facts in the trial as well as judicial and sociological considerations.
\end{abstract}

Keyword: criminal act; copulation; child; punishment; fornication. 


\section{A. PENDAHULUAN}

Teknologi yang semakin modern selain menunjukkan keunggulannya dan memberikan kemudahan untuk manusia, disisi lain juga teknologi mempunyai pengaruh negatif yang sangat besar untuk kalangan masyarakat terutama para remaja yang akan meranjak dewasa yang masih mencari jati dirinya untuk menjadi diri sendiri. Pengaruh negatif ini memberikan dampak yang sangat besar untuk para remaja sehingga menyebabkan banyaknya kejahatan yang sering dilakukan oleh anak remaja yang masih duduk dibangku SMP dan SMA. Akibat rasa ingin tahu tanpa didampingi dan bimbingan yang positif dari orang tua sehingga mereka (anak-anak remaja) mencari tahu dengan jalan yang tidak sesuai dengan kaidah Islam yang sudah diajarkan dan menjadi pedoman umat muslim untuk menjalankan perintahNya dan menjauhi laranganNya. Koneksi Internet yang mudah didapatkan menjadi para remaja mudah menggunakan internet selain itu juga fitur iklan porno di internet yang selalu muncul ketika membuka google diawal pencarian tujuan kita. Para remaja yang sering menonton video porno, membaca buku yang berisi seks dan serta pengaruh lingkungan akibat salah pergaulan.Faktor tersebut menjadikan kejahatan seksualitas terhadap perempuan maupun anak.

Dalam hal tindak pidana persetubuhan terhadap anak, sebenarnya perangkat perundang-undangan di Indonesia sudah cukup lengkap, yaitu terdapat di Kitab Undang-Undang Hukum Pidana dan Undang-Undang Nomor. 35 Tahun 2014 tentang Perubahan atas UU RI No 23 tahun 2002 tentang Perlindungan Anak, selain itu juga terdapat dalam Undang-Undang Nomor. 4 Tahun 1979 tentang Kesejahteraan Anak.Akan tetapi dari masa ke masa kejahatan itu selalu tumbuh dan berkembang di dalam lingkungan masyarakat. Dalam penulisan tesis ini, contoh kasus yang terkait dengan tindak pidana persetubuhan pada anak, sebagaimana yang hendak penulis teliti adalah terjadinya tindak pidana persetubuhan pada anak di Semarang, yang telah diputus oleh Pengadilan Negeri Semarang dengan No: 98/PID.SUS/2015/PN.Smg. 
Akibat perbuatan pelaku berdasarkan hasil Visum Et Repertum No. 4954/JM.050/MS-MR/K/15 RSUD Telogorejo Semarang. ${ }^{1}$

Berdasarkan fakta-fakta dalam persidangan telah diajukan tiga orang saksi disamping keterangan terdakwa yaitu Bayu Setiawan alias KIPLI Bin Moch.Salim dan alat bukti. Dan dalam Putusan Nomor 98/PID.SUS/2015/PN.SMG memberikan barang bukti yang ditujukan dalam persidangan yaitu sebagai berikut: ${ }^{2}$

1. 1 (Satu) buah kaos dalam warna merah merek Miss Understood;

2. 1 (Satu) buah celana dalam warna putih (tanpa merek);

3. 1 (satu) buah kaos tanpa kerah warna abu-abu merek Big Ocean.

4. 1 (satu) buah celana pendek loreng warna abu-abu (tanpa merek).

Ketentuan tindak pidana persetubuhan pada anak termuat dalam Pasal 81 ayat (2) UU No. 35 Tahun 2014 tentang perlindungan anak yang rumusannya sebagai berikut: 'Setiap orang dengan sengaja melakukan tipu muslihat, serangkaian kebohongan atau membujuk anak melakukan persetubuhan dengannya atau dengan orang lain”. Berdasarkan latar belakang penelitian di atas, maka penulis tertarik untuk melakukan penelitian dengan judul "Tindak Pidana Persetubuhan Terhadap Anak Jika ditinjau dari Hukum Positif dan Hukum Islam.

\section{B. PERMASALAHAN}

Sesuai dengan uraian latar belakang di atas, maka dalam penelitian ini dapat dirumuskan masalah sebagai berikut :

1. Bagaimana pelaku tindak pidana persetubuhan terhadap anak menurut Hukum Positif dan Hukum Islam?

2. Bagaimana pertimbangan hukum oleh hakim dalam menjatuhkan putusan terhadap tindak pidana persetubuhan pada anak menurut Hukum Positif dan Hukum Islam.? 
$e-I S S N: 2621-4105$

\section{METODE PENELITIAN :}

\section{Metode Pendekatan}

Metode merupakan hal yang cukup penting untuk mencapai tujuan dari penelitian itu sendiri.Untuk mendapatkan data-data yang jelas dan ketajaman menganalisa.

\section{Spesifikasi Penelitian}

Spesifikasi penelitian yang digunakan dalam penulisan hukum ini adalah deskriptif analitis yaitu penelitian yang menggambarkan atau mendeskripsikan objek penelitian secara umum kemudian menganalisis peraturan perundangundangan yang berlaku dikaitkan dengan teori-teori hukum dalam praktek pelaksanaan hukum positif yang mengangkut permasalahan tentang tindak pidana perlindungan anak menurut UU No. 23 tahun 2002: studi kasus Putusan No.130/PID.SUS/2014/PN.Smg.

\section{PEMBAHASAN}

\section{Tinjauan Umum Tindak Pidana}

Tindak Pidana berasal dari terjemahan bahasa Belanda straafbaarfeit, dikenal juga dengan istilah delict yang berasal dari bahasa latin delictum. ${ }^{3}$ Simons menerangkan, strafbaar feit adalah kelakuan (handeling) yang diancam dengan pidana, yang bersifat melawan hukum, yang berhubungan dengan kesalahan dan yang dilakukan oleh orang yang mampu bertanggungjawab. ${ }^{4}$ Sedangkan Van Hamel merumuskan starfbaar feit adalah kelakuan orang (menselijke gedraging) yang dirumuskan dalam wet, yang bersifat melawan hukum, yang patut dipidana (strafwaardig)dan dilakukan dengan kesalahan. ${ }^{5}$ Sedangkanmenurut Teguh Prasetyo, tindak pidana adalah:

Perbuatan yang oleh aturan hukum dilarang dan diancam dengan pidana. Pengertian perbuatan di sini selain perbuatan yang bersifat aktif (melakukan

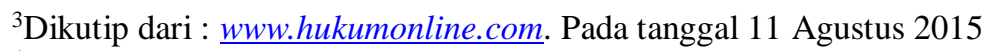

${ }^{4}$ Andi Hamzah, Terminologi Hukum Pidana, (Jakarta:Sinar Grafika, 2009), halaman 48.

${ }^{5}$ Ibid, halaman 56
} 
sesuatu yang sebenarnya dilarang oleh hukum) dan perbuatan yang bersifat pasif (tidak berbuat sesuatu yang sebenarnya diharuskan oleh hukum). ${ }^{6}$

Menurut Jonkers, tindak pidana adalah: 7 "Suatuperbuatan yang melawanhukum (wedwerrechtelijk) yang berhubungan dengan kesengajaan atau kesalahan yang dilakukan oleh orang yang dapat dipertanggungjawabkan.”

\section{Unsur-Unsur Tindak Pidana}

Setiap tindak pidana yang terdapat dalam KUHP pada umumnya dapat dijabarkan ke dalam unsur-unsur yang terdiri dari unsur subjektif ${ }^{8}$ dan unsur objektif. ${ }^{9}$

Unsur-unsur subjektif dari suatu tindak pidana adalah :

a. Kesengajaan (dolus) atau ketidaksengajaan (culpa);

b. Maksud atau Voornemen pada suatu percobaan atau poging seperti yang dimaksud dalam Pasal 53 ayat (1) KUHP;

c. Macam-macam maksud atau oogmerk seperti yang terdapat dalam kejahatan-kejahatan pencurian, penipuan, pemerasan, pemalsuan, dan lainlain;

d. Merencanakan terlebih dahulu atau voorbedachteraad yang terdapat dalam kejahatan pembunuhan menurut Pasal 340 KUHP;

e. Perasaan takut yang antara lain terdapat dalam rumusan tindak pidana menurut Pasal 308 KUHP $^{10}$

Unsur-unsur objektif dari suatu tindak pidana adalah sebagai berikut :

a. Sifat melawan hukum atau wederrechttelijkheid;

b. Kualitas dari pelaku, misalnya keadaan sebagai seorang pegawai negeri;

c. Kausalitas, yakni hubungan antara suatu tindak pidana sebagai

\footnotetext{
${ }^{6}$ Teguh Prasetyo, Hukum Pidana Edisi Revisi, (Jakarta:PT Raja Grafindo Persada, 2011), halaman 49.

${ }^{7}$ Adami Chazawi, Pelajaran Hukum Pidana I, (Jakarta: PT Raja Grafindo Persada, 2010), halaman 75 .

${ }^{8}$ Unsur subjektif adalah unsur-unsur yang melekat pada diri pelaku atau yang berhubungan dengan pelaku dan termasuk ke dalamnya segala sesuatu yang terkandung di dalam hatinya.

${ }^{9}$ Unsur objektif adalah unsur-unsur yang ada hubungannya dengan keadaan-keadaan, yaitu

di dalam keadaan keadaan mana tindakan-tindakan dari pelaku harus dilakukan.

${ }^{10}$ P.A.F. Lamintang, Dasar-Dasar Hukum Pidana Indonesia, (Bandung: Citra Aditya Bakti, 2006), halaman 193-194.
} 
penyebab dengan sesuatu kenyataan sebagai akibat. ${ }^{11}$

Selain itu, unsur-unsur tindak pidana dapat dilihat menurut beberapa teoritis. Teoritis artinya berdasarkan pendapat para ahli yang tercermin pada bunyi rumusannya. ${ }^{12}$

\section{Tinjauan Umum tentang Anak dalam Hukum Positif}

\section{a. Pengertian Anak}

Secara umum dikatakan anak adalah seorang yang dilahirkan dari perkawinan antar seorang perempuan dengan seorang laki-laki dengan tidak menyangkut bahwa seseorang yang dilahirkan oleh wanita meskipun tidak pernah melakukan pernikahan tetap dikatakan anak.

\section{b. Pengertian Perlindungan Anak}

Menurut Arif Gosita, "Suatu kegiatan bersama yang bertujuan mengusahakan pengamanan, pengadaan dan pemenuhan kesejahteraan rohani dan jasmani anak atau remaja yang sesuai dengan kepentingan hak asasinya."13

Zulkhair merumuskan bahwa :

Perlindungan anak adalah segala upaya yang ditujukan untuk mencegah, merehabilitasi dan memperdayakan anak yang mengalami tindak perlakuan yang salah, eksploitasi dan pelantaran agar dapat menjamin kelangsungan hidup dan tumbuh kembang anak secara wajar baik fisik, mental maupun sosial. ${ }^{14}$

Pasal 1 angka 2 UU No. 23 Tahun 2002 sebagaimana diubah dengan UU No. 35 Tahun 2014 menyatakan: "Perlindungan anak adalah segala kegiatan untuk menjamin dan melindungi anak dan hak-haknya agar dapat hidup tumbuh, berkembang, dam berpartisipasi secara optimal sesuai dengan harkat dan martabat dari kekerasan dan diskriminasi."

Menurut R. Soesilo persetubuhan adalah "perpaduan antara kelamin laki-laki dan perempuan yang biasanya dijalankan untuk mendapatkan anak, jadi anggota

\footnotetext{
${ }^{11}$ Adami Chazawi, Pelajaran Hukum Pidana 1, (Jakarta : PT Raja Grafindo Persada, 2006), halaman 79 .

${ }^{12}$ Ibid, halaman 82

${ }^{13}$ Arif Gosita, Perlindungan Anak, (Jakarta:Sinar Grafika, 2004), halaman 18.

${ }^{14}$ Ibid, halaman 20.
} 
kemaluan laki-laki harus masuk ke dalam anggota kemaluan perempuan sehingga mengeluarkan air mani"

Hukum bagi pelaku zina baru dapat ditetapkan apabila memenuhi unsurunsur perbuatan zina dengan beberapa kriteria.Pertama, melakukan persetubuhan di luar perkawinan yang sah dan disengaja. ${ }^{15}$ Persetubuhan dianggap zina minimal dengan terbenamnya hasyafah (pucuk zakar) pada farji, sekalipun tidak ereksi. ${ }^{16}$

Memberikan penjelasan bahwa zina adalah persetubuhan yang dilakukan di luar perkawinan yang sah.Hal ini berbeda dengan rumusan KUHP, bahwa zina hanya berlaku jika kedua pelaku sedang terikat perkawinan yang sah.Maka hanya pelaku yang sedang terikat dalam perkawinan yang sah saja yang dapat dijerat oleh pasal perzinaan

Perzinaan merupakan permasalahan yang sangat kompleks karena menyangkut berbagai aspek kehidupan masyarakat. Kegiatan prostitusi menyangkut aspek sosial, gender, hukum, kesehatan, moral dan etika,agama, pendidikan, psikologis, ekonomi dan industrialisasi, dan juga masalah politik.

Permasalahan yang diakibatkan oleh perzinaan, antara lain: ${ }^{17}$

1. Ditinjau dari segi pendidikan, prostitusi berarti demoralisasi;

2. Ditinjau dari segi sosial, prostitusi dianggap kanker masyarakat;

3. Ditinjau dari sudut agama, prostitusi adalah haram;

4. Ditinjau dari sudut kesehatan, prostitusi membahayakan keturunan;

\section{Pertimbangan Hakim dalam menjatuhkan Putusan terhadap Tindak Pidana}

Persetubuhan pada anak ditinjau dari Hukum Positif dan Hukum Islam.

Menurut Pasal 1 Undang-Undang No. 8 Tahun 1981 tentang Kitab UndangUndang Hukum Acara Pidana (KUHAP), hakim adalah pejabat Peradilan Negara yang diberi wewenang oleh undang-undang untuk mengadili. Kemudian kata “mengadili” sebagai rangkaian tindakan hakim untuk menerima, memeriksa, dan

\footnotetext{
${ }^{15}$ Surat Tashih dari Lajnah Pentashih Mushaf Al-Qur'an Departemen Agama (Semarang : Citra Effhar, 1993), hal. 568

164Abdul Qadir Audah, Ensiklopedi..., hal. 154

${ }^{17}$ Soedjono D., Pelacuran Ditinjau Dari Segi Hukum Dan Kenyataan Dalam Masyarakat, (Bandung:Karya Nusantara, 1997), hlm 109.
} 
memutus perkara berdasarkan asas bebas, jujur, dan tidak memihak dalam sidang suatu perkara dan menjunjung tinggi 3 (tiga) asas peradilan yaitu; sederhana, cepat dan biaya ringan.

\section{Dakwaan}

JPU dalam kasus ini, berdasarkan putusan No.98/PID.SUS/2015/PN.Smg.JPU mengajukan Terdakwa Bayu Setiawan dengan dakwaan berbentuk alternatif, surat dakwaan dengan No. 98/Pen.Pid/Sus/2015/PN.Smg adalah sebagai berikut:

\section{Dakwaan Pertama:}

Bahwa terdakwa Bayu Setiawan pada hari Selasa tanggal 24 Februari 2015 bertempat di kost di daerah sendangguwo Kota Semarang, setidak-tidaknya disuatu tempat dalam daerah hukum Pengadilan Negeri Semarang di daerah tempat kejadian terjadi, maka sesuai Pasal 81 ayat (2) UU No. 23 Tahun 2002 tentang Perlindungan Anak, Pengadilan Negeri Semarang berwenang mengadili, dengan sengaja melakukan tipu muslihat, serangkaian kebohongan atau membujuk anak melakukan persetubuhan dengannya atau dengan orang lain. Perbuatan Terdakwa Bayu Setiawan sebagaimana diatur dan diancam pidana dalam Pasal 81 ayat (2) Undang-Undang Perlindungan Anak.

Atau

Dakwaan kedua :

Bahwa perbuatan terdakwa sebagaimana diatur dan diancam pidana Pasal 287 KUHP.

Dakwaan ketiga :

Bahwa perbuatan terdakwa sebagaimana diatur dan diancam pidana dalam Pasal 332 ayat (1) ke-1 KUHP.

\section{Pembuktian}

Alat bukti adalah segala sesuatu yang ada hubungannya dengan suatu perbuatan, dimana dengan alat-alat bukti tersebut, dapat dipergunakan sebagai bahan pembuktian guna meyakinkan hakim atas kebenaran adanya suatu tindak 
pidana yang telah dilakukan terdakwa. Berdasarkan Pasal 184 KUHAP menyebutkan:

1). Alat bukti yang sah ialah:

a. Keterangan saksi;

b. Keterangan ahli;

c. Surat;

d. Petunjuk;

e. Keterangan terdakwa.

2). Hal yang secara umum sudah diketahui tidak perlu dibuktikan.

Dalam kasus ini berdasarkan Putusan No.98/PID.SUS/2015/PN.Smg, alat bukti yang diajukan adalah keterangan hasil Visum, keterangan 3 orang saksi dan keterangan Terdakwa Bayu Setiawan.

\section{Penuntutan}

Pada intinya JPU dalam perkara ini, menuntut sebagai berikut :

Menjatuhkan pidana kepada Terdakwa Bayu Setiawan dengan pidana penjara selama 8 tahun dan denda sebesar Rp. 500.00.000,00. Selain itu juga Terdakwa Bayu Setiawan dibebani untuk membayar biaya perkara sebesar Rp.2000.- (dua ribu rupiah).

\section{Putusan}

Berdasarkan putusan No.98/PID.SUS/2015/PN.Smg, bahwa Terdakwa Bayu Setiawan terbukti melakukan tindak pidana persetubuhan pada anak dan memenuhi Pasal 81 ayat (2) KUHP setiap orang dengan sengaja melakukan tipu muslihat, serangkaian kebohongan atau membujuk anak melakukan persetubuhan dengannya atau dengan orang lain.

\section{Amar Putusan:}

Majelis hakim pada kasus tindak pidana persetubuhan pada anak menurut hukum positif dan hukum islam, pada pokoknya menjatuhkan pidana penjara selama 3 tahun dengan pidana denda sebesar Rp 60.000.000,- apabila Terdakwa Bayu Setiawan tidak bisa membayar pidana denda maka diganti dengan pidana 
kurungan selama 2 bulan. Selain itu Terdakwa Bayu Setiawan telah dinyatakan bersalah dan harus dihukum, maka Terdakwa Bayu Setiawan harus dibebani untuk membayar biaya sebesar Rp. 2.000,00 (dua ribu rupiah) dalam Pasal 222 KUHAP, mengacu pada Pasal 8 ayat (2) UU No. 48 Tahun 2009 tentang Kekuasaan Kehakiman yang isinya sebagai berikut "Dalam mempertimbangkan berat ringannya pidana, haki wajib memperhatikan pula sifat yang baik dan jahat dari terdakwa.” Dan Pasal 197 KUHAP.

Berdasarkan paparan di atas dapat diketahui bahwa penerapan hukum pidana terhadap tindak pidana persetubuhan pada anak menurut hukum positif dan hukum islam. Yang dilakukan oleh Terdakwa Bayu Setiawan telah sesuai dengan procedure yang diatur dalam KUHAP. Pemidanaan berdasarkan pada fakta-fakta dalam persidangan, tuntutan, dakwaan, pembuktian, tuntutan, unsur-unsur pasal yang terpenuhi.

\section{a. Pertimbangan Yuridis}

Dalam menjatuhkan putusan terhadap suatu perkara, terlebih putusan bebas (vrijspraak), hakim harus benar-benar menghayati arti amanah dan tanggung jawab yang diberikan kepadanya sesuai dengan fungsi dan kewenangannya masing-masing.

Lilik Mulyadi mengemukakan bahwa :

Hakikat pada pertimbangan yuridis hakim merupakan pembuktian unsur-unsur dari suatu tindak pidana yang dapat menunjukkan perbuatan terdakwa tersebut memenuhi dan sesuai dengan tindak pidana yang didakwakan oleh penuntut umum sehingga pertimbangan tersebut relevan terhadap amar atau diktum putusan hakim. ${ }^{18}$

\section{b. Pertimbangan Sosiologis}

Kedudukan rakyat Indonesia dalam penegakan hukum tertuang dalam Pasal 27 ayat (1) Undang-Undang Dasar 1945 yang rumusannya: "Segala warga negara bersamaan kedudukannya di dalam hukum dan pemerintahan

${ }^{18}$ Lilik Mulyadi, Putusan Hakim dalam Hukum Acara Pidana; Teori, Praktik, Tehnik penyusunan dan Permasalahannya, (Bandung : Citra Aditya Bakti, 2009), halaman 193 
dan wajib menjunjung hukum dan pemerintahan itu dengan tidak ada kecualinya."

Sebagai upaya pemenuhan yang menjadi kedudukan rakyat ini, maka dikeluarkan berbagai peraturan perundang-undangan yang salah satunya adalah Undang-Undang Nomor 48 Tahun 2009 tentang Kekuasaan Kehakiman dengan tujuan agar penegakan hukum di negara ini dapat terpenuhi. Salah satu Pasal dalam Undang-Undang Nomor 48 Tahun 2009 yang berkaitan dengan masalah ini adalah hakim sebagai penegak hukum menurut Pasal 5 ayat (1) Undang-Undang No. 48 Tahun 2009 bahwa "Hakim wajib menggali, mengikuti, dan memahami nilai-nilai hukum dan rasakeadilan yang hidup dalam masyarakat".

\section{E. PENUTUP}

Pemidanaan terhadap pelaku tindak pidana persetubuhan pada anak ditinjau dari hukum positif dan hukum islam sesuai dengan prosedure, pelaku tersebut dapat diberikan sanksi atau hukuman dengan 2 cara yang pertama Hukum Positif yang mengacu pada KUHP dan KUHAP dapat dipidana penjara dan saksi denda, apabila di sisi Hukum Islam terdakwa diberikan sanksi berupa dera atau cambukan sebanyak 100 kali. Pertimbangan hakim dalam menjatuhkan putusan terhadap tindak pidana persetubuhan pada anak ditinjau dari hukum positif dan hukum islam adalah pertimbangan yuridis yang meliputi dakwaan, pembuktian, fakta-fakta dalam persidangan, tuntutan, unsur-unsur Pasal 81 ayat (2) UU No. 35 Tahun 2014 tentang Perubahan Atas UU Nomor 23 Tahun 2004 tentang Perlindungan Anak dan pertimbangan sosiologis yang meliputi latar belakang sosiologis Terdakwa Bayu Setiawan, hal-hal yang meringankan dan hal-hal yang memberatkan. Di dalam Putusan Nomor.98/PID.SUS/2015/PN.Smg, hakim menjatuhkan pidana terhadap terdakwa Bayu Setiawan dengan pidana penjara selama 3 (tiga) tahun dan denda sebesar Rp. 60.000.000,- (Enam puluh juta rupiah) dengan ketentuan apabila denda tidak dibayar diganti dengan pidana kurungan selama 2 (dua) bulan. 
e-ISSN : 2621-4105

\section{DAFTAR PUSTAKA}

\section{Buku}

Abdul Wahid \& Muhammad Irfan, 2001, Perlindungan Terhadap Korban Kekerasan Seksual, CetakanPertama, RefikaAditama

Adami Chazawi, 2007, Tindak Pidana Mengenai Kesopanan, Raja Grafindo Persada.Jakarta.

Andi Hamzah, 2005, Asas-Asas Hukum Pidana, Cetakan Pertama, Yarsif Watampone. Jakarta.

Andi Zainal Abidin Farid,2007, HukumPidana 1. Cetakan kedua, Sinar Grafika.Jakarta.

ArifGosita, 1993, Masalah Korban Kejahatan (Kumpulan Karangan) Akademi Pressindo, Jakarta.

Bagong Suyanto, 2003, Masalah Sosial Anak. Cetakan Pertama, Kencana. Jakarta.

Gatot Supramono, 2007, Hukum Acara Pengadilan Anak. Cetakan ketiga, Djambatan. Jakarta

Hakim, Rahmat, HukumPidana Islam (FiqhJinayah), Bandung : Pustaka Setia, 2000 Kadi sukarna, 2011, Alat Bukti Petunjuk Menurut KUHAP dalam Persepektif Teori Keadilan, Uness Press. Semarang.

John Ibrahim, 2006, Teoridan Metode Penelitian Normatif, Malang: Bayumedia

Leden Marpaung, 2008, Kejahatan Terhadap Kesusilaan, Cetakan ketiga, Sinar Grafika. Jakarta.

Lilik Mulyadi, 2007, Hukum Acara Pidana (Normatif, Teoretis, Praktikdan\ Permasalahannya), Alumni, Bandung

Munajat, makhruh, FiqhJinayah (Norma-Norma HukumPidana Islam), 2008. Jogjakarta: FakultasSyari'ah Press,

Mahrus Ali, 2011, Dasar-Dasar Hukum Pidana, Cetakan pertama, Sinar Grafika.Jakarta.

Moeljatno, 1983, Azas-azas HukumPidana, Cetakan Pertama, Bina Aksara

Munajat, makhruh, Fiqh Jinayah (Norma-Norma Hukum Pidana Islam), 2008. Jogjakarta: FakultasSyari'ah Press.

John Rawls, 2006, A Theory of Justice, London: Oxford Univercity press, 1973, Teori

Keadilan, Terjemahaan Uzair Fauzan dan Heru Prasetyo, Yogjakarta: Pustaka Pelajar.

R.Soesilo, 1996, Kitab Undang-undang Hukum Pidana (KUHP) serta komentarKomentarnya lengkap pasal demi pasal, Politea. Bogor

Sudarto, 1990, HukumPidana I, Cetakan Kedua, Fakultas Hukum UNDIP, Semarang.

Undang - Undang 
e-ISSN : 2621-4105

Sekretariat Negara R.I Undang-undangNomor 1 Tahun 1974 Tentang Perkawinan.Jakarta, 1974

Sekretariatan Negara R.I KitabUndang-undang Hukum Acara Pidana (KUHAP).Jakarta, 1981

Sekretariat Negara R.I Undang-undangNomor 3 Tahun 1997 Tentang Pengadilan Anak. Jakarta, 1997

Sekretariat Negara R.I Undang-undangNomor 3 Tahun 1997 Tentang PengadilanAnak. Jakarta, 1997

Sekretariat Negara R.I Undang-undangNomor 23 Tahun 2002 Tentang PerlindunganAnak. Jakarta, 2002

Sekretariat Negara R.I Undang-undang Nomor 11 Tahun 2012 Tentang Sistem Peradilan Perlindungan Anak. Jakarta, 2012

PutusanPengadilan:

Putusan Pengadilan Negeri Semarang Nomor: 98/PID.SUS/2015/PN.SMG 